\title{
ESTIMATED ACCURACY COMPARISON OF FETAL WEIGHT BETWEEN JOHNSON TOSHACH FORMULA AND DARE FORMULA TOWARDS BABIES BIRTH WEIGHT
}

\author{
Dewi Nur Hidayah ${ }^{1)}$ Sinar Pertiwi ${ }^{2)}$ Etin Rohmatin ${ }^{3)}$ \\ dewihidayah60@gmail.com \\ Health Polytechnic of Tasikmalaya \\ Midwifery Department
}

\begin{abstract}
Background: The estimated accuracy of birth weight is a key element in early labor. The accurate fetal weight prediction method is an act of preventive to overcome the complications that are expected to reduce morbidity and mortality in childbirth.

Purpose: To determine the comparison of the estimated accuracy fetal weight between the Johnson Toshach formula and Dare formula against the baby's birth weight.

Method: This study is an analytic survey with a cross-sectional in Labour Room and Perinatology of Dr.Soekardjo hospitals in January and February 2019. The sample in this study using purposive sampling totally 96 respondents. Data analysis was performed by univariate and bivariate using paired t-test, independent t-test.

Results: There is no difference in fetal weight estimation between Johnson Toshach formula and Dare formula with the birth weight ( $\rho$ value $>0.1$ ). The results of the diagnostic test for Johnson Toshach formula provides the accuracy (87.5\%) and the Dare formula (91.7\%).

Conclusion:Dare formula is more accurate in determining the estimated fetal weight compared to Johnson Toshach formula.

\section{Keywords : Estimated Fetal Weight, Johnson Toshach Formula, Dare Formula \\ 1) Student of DIV Midwifery Study Program, Health Polytechnic of Tasikmalaya \\ ${ }^{2,3)}$ Lecturer at the Midwifery Department, Health Polytechnic of Tasikmalaya}

Background. Infant Mortality Rate (IMR) is the number of dead infants (under 1 year) per 1,000 live births. Neonatal Mortality Rate (NMR) is a death that occurs before the baby is one month old or 28 days per 1,000 live births in a year. Infant and neonatal mortality rates used as indicators that are sensitive to the utilization, availability, and quality of health services, especially perinatal care and reflect the level of development of a country's health and quality of life of its people (Darmayanti, 2009).
The world's Infant Mortality Rate (IMR) according to the United Nations International Children's Emergency Fund (UNICEF) in 2017 is 29.4 per 1,000 live births, while the world's neonatal mortality rate is 18 per 1,000 live births (UNICEF, 2017).

The neonatal mortality rate in Southeast Asian countries especially Indonesia in 2016 is 15 per 1000 births. It means that the neonatal mortality rate in Indonesia has not approached the target of SDGs (Sustainable Development Goals) - to lower the 
neonatal mortality rate to 12 per 1,000 live births (WHO 2018).

Indonesian Health Profile 2016 shows IMR of 24 per 1,000 live births and the NMR at 15 per 1,000 live births. As the incidence of infant mortality in West Java Province in 2016 as many as 3702 cases (Profil Kesehatan Indonesia, 2016).

Based on the causes, infant mortality can be divided into direct and indirect causes. The direct causes such as low birth weight (LBW), postnatal infection, hypothermia also asphyxia and indirect causes such as the mother condition during pregnancy, health services provided, socioeconomic factors and environmental influences. One cause of direct mortality is low birth weight infants. Birth weight is a determinant in infant growth and survival. (Dewi, 2010).

Based on the description above, it needed a way to determine fetal wellbeing, through the estimate fetal weight during pregnancy and delivery. Estimated fetal weight is one way to interpret the weight of the fetus while still in the uterus (Kusmiyati et al, 2011).

The precision or accuracy of the estimated birth weight is a key element in early labor. Accuracy is the degree of proximity measurement of the actual value (JCGM 2010). This accurate prediction method of fetal weight performed preventive measures to cope with complications that may occur when the birth weight is low or high (Mortazavi and Akaberi, 2010).

There are various ways to determine the Estimated Fetal Weight (EFW), there are two methods can be used to measure the estimated weight of the fetus, by ultrasound and clinical examination. Ultrasound can be used to determine the growth of fetal weight by gestational age. But the availability of the tools and human resources are still limited. So, it needs an alternative to monitor the growth of fetal weight.

One easy way to estimate fetal weight is a measure the height of uterine and estimated fetal weight using a specific formula. Several formulas use fundus uteri's height to estimate the weight of the baby - Toshach Johnson formula, Dare formula, Niswander formula, and the Rusanto formula (Saputra, 2014).

Determining fetal weight accuracy would be better to do a comparison of other formulas, hopefully of fetal weight estimates obtained closest to the birth weight. Several formulas can be considered in determining the estimated fetal weight is the use of equations also Dare and Johnson Toshach formulas. Recently, Johnson Toshach formula is a formula that is still commonly used in clinical practice to determine the estimated fetal weight based on height measurements of the fundus and a digression in the bottom of the fetus. While the Dare formula proposes a formula that is more simple, objective and easily taught. The method used in the form of the mother's abdominal circumference measurements in centimeters and then multiplied by the size of the fundus in centimeters, then it will get the estimated fetal weight (Irianti et al, 2015).

The data obtained in Dr. Soekardjo Hospital from January to September 2018, LBW most to 3 diagnoses. The first diagnosis is asphyxia with 2317 cases, 879 cases of jaundice, and LBW with 484 cases. Based on the data we can conclude that a predisposing factor of asphyxia or jaundice, one of which was LBW.

Based on a preliminary study conducted by researchers by interviewing the head of the delivery room in Dr.Soekardjo Hospital. Fundus uteri's height (FUH) examinations 
procedure is on Leopold Operational Standard Procedure and when examining FUH, the mother's head position propped pillows around $15^{\circ}$ (supination position - Toshach Johnson formula). The abdominal circumference measurement was done only in certain cases because it was also worth considering the estimated weight of the fetus, but only measured, not calculated by a certain formula. Midwives at the hospital do not know the Dare formula to calculate the fetus's weight.

In a previous study conducted by Saputra (2014) with the title 'The Estimated Accuracy Ratio of Fetal Weight by Dare Formula to Toshach Johnson Formula,' it was found that no significant difference in the Dare formula. Dare Formula closer to the baby's birth weight.

Therefore, the authors are interested in researching with the title: "The Estimated Accuracy Comparison of Fetal Weight Between Jonhson Toshach Formula and Dare Formula Towards Babies Birth Weight in Dr.Soekardjo Hospital Tasikmalaya City 2019 ".

Purpose. The purpose of this study is to compare the estimated accuracy of fetal birth weight by the Johnson Toshach formula and Dare formula in Dr. Soekardjo Tasikmalaya in 2019.

Method. The type of this research is an analytical survey, by using crosssectional. Data collecting is using primary data. This research was conducted in January and February 2019 in the delivery and perinatology room of Dr.Soekardjo Hospital, Tasikmalaya City.

The population in this study is all mothers in the delivery room of Dr. Soekardjo Hospital in the period of January to September 2015 as the birth rate. Technical sampling by nonprobability sampling with purposive sampling. The sample size of this study 96 people.

The sample in this research is all the respondents according to the specified conditions -inclusion and exclusion,

Inclusion criteria are singleton pregnancies, gestational age $\geq 37-\leq 42$ weeks, cephalic presentation, in part stages 1 , intact amniotic, do not look at the type of labor and are willing to become respondents (signed the informed consent). The exclusion criteria included Gemelli aberration, hydramnios, oligohydramnios, and IUFD (Intra Uterine Fetal Death).

The independent variable in this study is the accuracy of fetal weight estimation with Johnson Toshach formula and Dare formula. While the dependent variable in this study is birth weight.

The research instrument used was systematic observation, used digital scales on Infant Warmer Scale Multysistem 2051 calibration December 21, 2017, ONE MED measuring tape and observation sheets, a list of tables and there are checklists in fundus uterine's height measurement and also abdominal circumference measurement.

Univariate analysis in this study will show the frequency distribution of estimated birth weight between the Johnson Toshach formula and the Dare formula.

Bivariate analysis using data obtained with the normality tested using Kolmogrove-Smirnov as the number of respondents $>50$. Then using statistical test paired t-test and independent t-test. Furthermore, to determine the sensitivity, specificity, accuracy rate, positive predictive value and negative predictive value using diagnostic tests (Dahlan, 2014).

\section{Result and Discussion. \\ Result}

1. Univariate analysis 
Table 1. Frequency Distribution of Estimated Fetal Weight by Johnson Toshach Formula towards Babies Birth Weight

\begin{tabular}{l|c|c}
\hline \multicolumn{1}{c|}{ Interval } & $\mathbf{F}$ & $\boldsymbol{\%}$ \\
\hline$<1500 \mathrm{~g}$ & 0 & 0 \\
\hline $1500-2455$ grams & 13 & 13.5 \\
\hline $2500-4000$ grams & 79 & 82.3 \\
\hline$>4000$ & 4 & 4.2 \\
\hline Total & 96 & 100 \\
\hline
\end{tabular}

Based on table 1, it shows that the estimated fetal weight by the formula Johnson Toshach as much $(82.3 \%)$ in the category 2500-4000 grams and no estimate fetal weight in the category of $<1500 \mathrm{~g}$.

Table 2. Frequency Distribution of Estimated Fetal Weight by Dare Formula towards Babies Birth Weight

\begin{tabular}{l|c|c}
\hline \multicolumn{1}{c|}{ Interval } & F & \% \\
\hline <1500 gram & 0 & 0 \\
\hline $1500-2455$ gram & 8 & 8,3 \\
\hline $2500-4000$ gram & 84 & 87,5 \\
\hline$>4000$ & 4 & 4,2 \\
\hline Jumlah & 96 & 100 \\
\hline
\end{tabular}

Based on table 2, it shows that the estimated fetal weight by the formula Dare as much $(87.5 \%)$ in the category 2500-4000 grams and no estimate fetal weight in the category of $<1500 \mathrm{~g}$.

Table 3. Frequency Distribution of Babies Birth Weight

\begin{tabular}{l|c|c}
\hline \multicolumn{1}{c|}{ interval } & F & \% \\
\hline$<1500 \mathrm{~g}$ & 0 & 0 \\
\hline $1500-2455$ grams & 13 & 13.5 \\
\hline $2500-4000$ grams & 81 & 84.4 \\
\hline$>4000 \mathrm{~g}$ & 2 & 2.1 \\
\hline total & 96 & 100 \\
\hline
\end{tabular}

Based on table 3, it known that the babies birth weight $(84.4 \%)$ in the category 2500-4000 grams and no estimate fetal weight in the category of $<1500 \mathrm{~g}$.
2. Bivariate analysis

a. Normality test

Normality test using Kolmogorov-Smirnov formula with the estimated fetal weight results by Toshach Johnson formula has a value of 0.424 , while the estimated fetal weight by Dare formula has a value of 0.267 , and for the baby's birth weight value is 0.437 . All data has a value (Sig.) $>\alpha(0,1)$, it can be interpreted that all the data are normally distributed. Then the analysis can proceed with parametric statistics.

This analysis can be seen that the mean value of these three groups are in the baby's weight range is $3000-3100$ grams. In the group of Dare Formula distribution of the data is closer to the birth weight is 446.77 rather than the Johnson Toshach formula ie 435.99.

b. Parametric analysis

From the test results can be seen that $\mathrm{t}$ table 0.681 and 1.661 (df 95) with the Sig. (2-tailed) of 0.498 . Therefore t $0.681<\mathrm{t}$ table 1,661 and the Sig. (2-tailed) $0.498>\alpha(0,1)$, it means that there are no significant differences estimated fetal weight by the formula Dare birth weight infants. Thus the null hypothesis (Ho) is accepted

Independent $\mathrm{T}$ Test Results Comparison of Estimated Fetal Weight With Johnson Toshach Formula and Dare Formulas to Babies Birth Weight from the table 4.8 can be seen that $t$ count equal to 0,879 and t table (df 190) 1,653 and the value of Sig. (2tailed) .380 . Because $t 0,879<\mathrm{t}$ table 1,653 and the Sig. (2-tailed) $0.380>\alpha(0,1)$. This means that 
there is no significant difference between the estimated fetal weight calculation using Toshach Johnson formula and Dare formula to birth weight babies. Thus the null hypothesis (Ho) is accepted.

3. Diagnostic Test

Diagnostic test with cut off point 3053 grams. The data presented are normally distributed then the cut off point using mean value.

From the results of the diagnostic test table can be seen that the estimated formula provides the possibility of truth, Toshach Johnson estimates $<3053$ ie $(83.3 \%)$ and the ability to provide estimates> 3053 grams of which $(91.7 \%)$ as well as the accuracy of the Johnson Toshach formula against the birth weight (87.5\%).

From the results of the diagnostic test table can be seen that the estimated formula provides the possibility of truth Dare estimates $<3053$ ie $(91.7 \%)$ and the ability to provide estimates> 3053 grams of which $(91.7 \%)$ as well as the accuracy of the formula Dare on the birth weight $(91,7 \%)$.

\section{Discussion}

1. Estimated Fetal Weight with Johnson Toshach Formula against Babies Birth Weight

The results of the analysis showed that the estimated fetal weight with Johnson Toshach formula is no significant difference with the estimated fetal weight against the baby's birth weight. The average difference between estimated fetal weight using Johnson Toshach formula, the baby's birth weight was 33.51.
From the analysis of the known value of Sig. (2-tailed) $0.111>\alpha$ $(0,1)$, it means that there are no significant differences of the estimated fetal weight by the Johnson Toshach formula against the baby's birth weight. The weight's average of newborns 3053.57 grams with a standard deviation of 467.99 grams while the average of estimated fetal weight using Johnson Toshach formula 3087.10 grams with a standard deviation of 435.99 grams.

In a previous study conducted by Prasetowati, Firda F, and Martini in 2009 in North Lampung Regency, comparing the results of interpretation of fetal weight by Johnson Toshach formula and Niswander formula against baby's birth weight, Johnson Toshach formula had a significant value that equal to 0.26 .

Numprasent (2004) in Damayanti (2009), Johnson Toshach formula can be used only at head presentation, where the previous inspectors perform high measurement fundus, lower head and inserted into the formula. To be able to measure the height of fundus, the bladder should be empty (Damayanti, 2009).

Johnson Toshach formula can be used as a formula for calculating the estimated fetal weight, because it is necessary to measure the entry of the head and pelvic examination, certain patients in inpartu conditions are not recommended. Many factors that the measurement or estimation can not be corrected as placenta previa, multiple pregnancy, uterine tumors, and hydramnios. 
2. Estimated Fetal Weight With Dare Formula Against Baby's Birth Weight

The results showed that the estimated fetal weight with Dare formula not significant difference with the real baby's birth weight. The average difference between estimated fetal weight with Dare formula against the baby's birth weight is 12.99 . From the analysis, the known value of Sig. (2-tailed) $0.498>\alpha(0,1)$, it means there are no significant differences in the estimated fetal weight with Dare formula against the baby's birth weight. The weighted average of newborns 3053.57 grams with a standard deviation of 467.99 grams while the average estimated fetal weight by Dare formula is 3066.56 grams with a standard deviation of 446.77 grams.

In a previous study by Dana Ricvan Nindrea 2017 in Satelit Hospital to determine differences in the estimated fetal weight by fetal weight calculation with Dare formula and Risanto formula. A comparison between the significance value of the Risanto formula even greater with the calculation of Dare formula with the birth weight is 0.484 . A similar study conducted by Erwin ES, Hotmail PP, M Fahdhy 2014 which compares the accuracy of estimated fetal weight by Dare formula and Johnson Toshach formula, the results showed that the Dare formula is more accurate.

The mother's abdominal circumference measurements is the method used by the size of the fundus in form of centimeters, then it will get the estimated fetal weight (Irianti et al, 2015). The examination to determine the estimated fetal weight with the calculation of fundus height and abdominal circumference as Dare formula is easy to learn and work in progress and is widely used in usual practice. Clinical method for the prediction of fetal weight using height measurements of the fundus and maternal abdominal circumference more objective and easy to teach (Malik, 2012).

Estimated fetal weight according to the calculation formula of baby's birth weight, mentioned that measuring abdominal girth gives a rough indication for fetal growth in meters. Increased abdominal circumference with a thickness of about $2.5 \mathrm{~cm}$ (1 inch) per week exceeded 30 weeks and at term of about $95.1 \mathrm{~cm}$ (38 inches to 40 inches). Usually, abdominal circumference increased until 38 weeks and remained stable by the length (Nindrea, 2017).

3. Estimated Accuracy Comparison of Fetal Weight With Johnson Toshach Formula and Dare Formula Against Birth Weight Babies

Based on the analysis we found that the difference between the average estimated fetal weight by the Johnson Toshach formula within the birth weight is 163.68 grams. While the difference in the average estimated fetal weight by the Dare formula is 148.56 grams. Dare formula has a smaller average than the Johnson Toshach formula. But statistically, Johnson Toshach and Dare formula against baby's birth weight didn't differ significant with the value of 0.380 .

Based on the second diagnostic to test the Johnson Toshach formula provide the accuracy $(87.5 \%)$ and 
the Dare formula (91.7\%). It can be concluded that the Johnson Toshach and Dare formula recommended to the formula in determining birth weight because there is no significant difference between both formulas against the baby's birth weight. But Dare formula is more accurate $(91.7 \%)$ according to the diagnostic test.

Conclusion. There were no significant differences in estimated fetal weight between Johnson Toshach formula and Dare formula against the baby's birth weight by the value of $\rho$ value $>\alpha(0,1)$.

There is no significant difference between Johnson Toshach formula and Dare formula against the baby's birth weight with $\rho$ value of 0.380 .

Diagnostic test results showed that Dare formula is more accurate, Johnson Toshach formulas provide an accuracy rate of $(87.5 \%)$, while the Dare formula gives an accuracy rate of (91.7\%).

\section{Suggestion.}

1. For Clients : To know the estimated fetal weight and possible complications.

2. For Health Institution : For Dr Soekardjo Hospital, can be considered in policymaking on the Operational Standard Procedure in measuring the estimated fetal weight and know the risk factors that occur during pregnancy so that it becomes the basis for the precision management of pregnancy and childbirth.

3. For Educational Institutions: The results of this study are expected to be a reference, documentation and library materials on how to calculate the estimated fetal weight by the Dare formula.

4. For Further Research : As a comparison or suggestion to conduct research with respondents which condition of not ruptured or broken amniotic membranes. Moreover, it can develop a research about estimated fetal weight with other formulas or add more complete study variables with the different research methods.

\section{References}

Ambarwati, DA. (2015) Rumus Risanto Akurat untuk Memperkirakan Taksiran Berat Badan Janin Berat Lahir Bayi di Puskesmas Patikraja Kabupaten Banyumas

Armini, NW., Sriasih NGA., Marhaeni GA. (2017) Asuhan Kebidanan Neonatus, Bayi, Balita dan Anak Prasekolah, ANDI, Yogyakarta

Dahlan, S. (2014) Statistik Untuk Kedokteran Dan Kesehatan Edisi

6, Salemba Medika, Jakarta

Darmayanti, E. (2009) Hubungan Lingkar Lengan Atas (LILA) Ibu Hamil dengan Taksiran Berat Janin (TBJ) di Wilayah Puskesmas Sukodono Kabupaten Sragen, Other thesis, Universitas Sebelas Maret

Dewi, VNL. (2010) Asuhan Neonatus Bayi dan Anak Balita, Salemba Medika, Jakarta

Irianti, B., Duhita, F., Mutiara, E. (2015) Asuhan Kehamilan Berdasarkan Bukti, CV Sagung Seto, Jakarta

JCGM. (2008) International Vocabulary of Metrology, Basic and General Concepts and Associated Terms (VIM 3rd edition)

Julianty. (2009) Perbandingan Akurasi Taksiran Berat Badan Janin Menggunakan Rumus Mc. Donald dengan Modifikasi 
Rumus Johnson Modifikasi Syahrir, Rumah Sakit Mohammadiyah Husein, Palembang

Kusmiyati, Y., Sajiyatini. (2011) Perawatan Ibu Hamil (Asuhan Ibu Hamil), EGC, Jakarta

Kementrian Kesehatan RI. (2017) Profil Kesehatan Indonesia 2016, Kementrian Kesehatan RI, Jakarta

Mortazavi, Akaberi, A. (2010) Estimation of Birth Weight by Measurements of Fundal Height and Abdominal Girhin Parturient at Term, Eastern Mediterranean Health Journal

Mandriwati, GA. (2012) Asuhan Kebidanan A ntenatal Edisi 2, ECG, Jakarta

Manuaba, S., Dewi, IASK. (2011) Kesehatan Reproduki Untuk Mahasisiwi Bidan, EGC, Jakarta

Morse, K., Amanda, W., Joson, G. (2009) Fetal Growth Screening by Fundal Height Measurement, Best Practice \& Research Clinical Obstetrics and Gynaecology

Nindrea, RD. (2017) Perbedaan

Taksiran Berat Badan Janin Menurut Formula Perhitungan Berat Badan Lahir, Program Pascasarjana S2 Kesehatan Masyarakat Fakultas Kedokteran Universitas Andalas (UNAND), Padang

Saifuddin, AB. (2009) Pelayanan Kesehatan Maternal Dan
Neonatal, PT Bina Pustaka, Jakarta

Saputra, EE. (2014) Perbandingan Akurasi Tasksiran Berat Badan Janin Menurut Formula Dare dengan Johnson Toshach, Fakultas Kedokteran Universitas Sumatera Utara, RSUP H Adam Malik Medan

Sudarti, E., Khoirunnisa. (2010) Asuhan Kebidanan Neonatus Bayi dan Anak Balita, Nuha Medika, Yogyakarta

Sugiyono. (2013) Metode Penelitian Pendidikan Pendekatan Kuantitatif, Kualitatif, dan $R \& D$, Alfabeta, Bandung

Titisari, HI. (2012) Perbandingan Akurasi Rumus Risanto dan Rumus Johnson dalam Menentukan Taksiran Berat Janin Berdasarkan Tinggi Fundus Uterus, Tesis, Fakultas Kedokteran Universitas Gadjah Mada Yogyakarta

The World Bank. (2018) Mortality Rate, Diakses tanggal 14 november 2018, Tersedia pada: https://data.worldbank.org/indi cator/SH.DYN.NMRT? end $=201$ $7 \&$ start $=9$

UNICEF. (2018) Neonatal Mortality Rate, Diakses tanggal 14 november 2018,_Tersedia pada: https://data.unicef.org/topic/chi ld-survival/neonatal-mortality/

WHO. (2018) Improving New Born and Child Health Strategi Farmwork 2018-2011, WHO Regional Office for South-East Asia 